\title{
Inclusion Of Criminal News In Daily Online Newspaper Haluan Padang: Theo Van Leeuwen Perspective
}

\author{
Reski Rahmayati, Ermanto, Harris Effendi Thahar \\ Universitas Negeri Padang \\ reskiasrul2@gmail.com
}

\begin{abstract}
This study aimed to analyze the using of inclusion perspective of Van Leeuwen's strategy in criminal news with narcotics theme in daily Online Newspaper Haluan Padang edition of February 2018th. There were 3 steps to collect the data (1) to read and understand discourse with narcotics theme in daily Online Newspaper Haluan Padang edition of February 2018th the goal is gain comprehension with the object of the research, (2) to mark the parts of discourse related to the inclusion perspective of Van Leeuwen's strategy, and (3) to inventory the phrase in the discourse associated with the inclusion perspective of Van Leeuwen's strategy data format inventory. This research type was qualitative research by using the descriptive method. Based on the results of the study it can be concluded that the inclusion strategy of Van Leeuwen's perspective found in five crime articles with narcotics theme in daily Online Newspaper Haluan Padang edition of February 2018 with total four from seven kinds of inclusions, objectivities-abstraction, nomination-categorization, assimilation-individualization, and association-disasosiasi. In the study of this analysis can be concluded that in writing criminal news with the theme of narcotics as whole journalists do not side with the perpetrators or actors. The form of non-alignment of journalists to perpetrators is to mention the name and crime of the perpetrator and sanctions to be given to the perpetrator for the deed he has done.
\end{abstract}

Keywords-criminal news; inclusion; Leeuwen; discourse

\section{INTRODUCTION}

The use of incubation strategies Theo Van Leeuwen is often used in research in various countries. Previous research on inclusion strategies has been done by Hodkinson \& Alan (2013), Harling \& Martin (2013), Remley \& Dirk (2009), Tange \& Hanne (2016), and Trilokekar, Desai, El Masri, Amira (2017). Hodkinson \& Alan (2013) is one of those who have done critical research using inclusion strategies in an educational policy discourse in the UK. In his findings he argued that inclusion as a "force" in regulating policy. The policy is based on pursuing equality and justice for children.

In Indonesia alone, research on inclusion strategy has been done by Ninit (2016). The object of his study is seven criminal stories with the theme of theft in Posmetro Padang Newspaper edition May 2013. He found the phenomenon in writing the criminal news reporters do not marginalize the victim. In addition, research on inclusion strategies was also undertaken by Oktavia \& Silitonga (2016). He conducted research on the implementation of critical discourse analysis of Leeuwen's perspective and the form of power contained in the discourse of political news. In his findings, he argues that there is a link between discourse and power. Power not only operates through formal channels, laws and state institutions with its power to ban and punish but also operate through a series of discourses to define something or a group as untrue or bad.

In contrast to the above relevant research, this study focuses more on the use of inclusion strategies using the Theo Van Leeuwen perspective. The analysis is done critically on crime news with the theme of narcotics in the daily online Newspaper of Haluan Padang edition February 2018. From these observations, the problem arises whether reporters side with the perpetrator or not depicted in the news text?

From the relevant research, it has not fully explained the use of inclusion strategy in a discourse, especially in the discourse of criminal news. Is it appropriate news discourse that is displayed with the actual events that occur? The researcher will present a critical analysis of the news discourse in the daily online newspaper of Haluan Padang edition in February 2018th and investigate the use of its inclusion strategy.

Mass media is a communication tool to convey the social reality or news that happened to the community. With the media, the power of power by displaying what is good and what is bad can be displayed. Not just a free channel, but also the media as a subject that can construct reality, complete with views, bias, and also ownership. (Eriyanto, 2009, p. 36).

Presentation of information by journalists on social media can by using media information and communication, such as with the print or electronic media. In presenting the news, journalists and mass media are influenced by certain groups or parties who have powers in presenting the events reported. It is intended to fight for its ideology as well as to 
marginalize other ideologies. In connection with the news, it is necessary to have a journalist's knowledge about the feasibility of a news story to be published.

The feasibility of a story to be published is described in Chapter II of Article 5 of the Journalism Journalism Code of Indonesian Journalists on the way news reports that "Journalists present the news in a balanced and fair manner, prioritizing the accuracy of speed and not confusing facts and opinions. Posts containing interpretations and opinions, presented with the author's obvious name ".

Based on the literature review, it is found that the number of users of narcotics in Indonesia to date amounts to 6.4 million people. The case is often published in the news, especially in the online media continuously. Every day there is news about criminals being published. For example, in the case of smuggling, use, or narcotics dealers. It can be said that almost no day without narcotics news in the mass media, especially the online mass media. The condition is certainly raises the question for many parties. What technique is actually used in presenting the news and how it describes it?

Based on these data, criminal news cases, especially with the narcotics theme that often occurs. It can not be denied that the media has different presentation styles in news writing. According to Nugroho (2008, p. 102) criminal events are widely used as news material because it is considered to attract the attention of many readers. So it is not uncommon to find the language monopoly done by journalists or media is against the journalistic code of ethics.

One of the mass media that often presents criminal news with the theme of narcotics is the online newspaper Haluan Padang Daily. To find out the inclusion in the crime news reported in the online newspaper Haluan Padang Daily, the researcher will present the analysis critically by using critical discourse analysis Theo Van Leeuwen. There are two points of interest in this discourse analysis model, namely the process of exclusion and inclusion. The process of exclusion means the process of expenditure, related to the question, whether there are actors (can be groups or persons) removed from the news. While inclusion, it is used to detect the depiction of social events / actors involved in the news. In this study is devoted to see how inclusion in a criminal news with the theme of narcotics. Whether it is illustrated as it is or is otherwise poorly portrayed. Eriyanto (2009, p. 178) argues that according to Leeuwen there are some discourse strategies when a person or group of people is displayed in the text, ie differentiation-indifferentiation, objtivations, nomenclature, nomination-identification, determinations, assimilation-individualization, disassociated.

\section{METHODS}

This research type is qualitative research by using a descriptive method. According to Moleong (2007, p. 7), qualitative research is a study that focuses more on the process than on results. Nazir (1988, p. 63) states that descriptive method is the way used to examine the status of human groups, an object, a condition, a system of thought in the present. In addition, data is collected using content analysis (content analysis) that is analyzing the content in the discourse in depth. The type of research used is very suitable with the model by analyzing descriptive data in the form of speech or writing and the behavior of people to be observed. This descriptive research is used to view, describe and analyze data related to inclusion perspective of Van Leeuwen strategy in crime news discourse at daily online newspaper Haluan Padang edition of February 2018th. The data used in this research are phrases, clauses, and sentences related to the inclusion perspective of Van Leeuwen strategy in criminal discourse in the daily online newspaper Haluan Padang edition of February 2018th. The source of this research data is daily online newspaper Haluan Padang edition of February 2018th.

\section{FINDING AND DISCUSSION}

The use of inclusion perspective of Van Leeuwen strategy in crime news with narcotics theme in daily online newspaper Haluan Padang edition of February 2018th.

The Van Leeuwen perspective inclusion strategy found on five criminal news with narcotics theme in daily online newspaper Haluan Padang edition of February 2018th are objtivities, categorizations, assimilationindividualizations, and associations. Of the four inclusion theories contain 36 data containing Van Leeuwen's perspective. The description of inclusion perspective of Van Leeuwen strategy found on five criminal news with narcotics theme on daily online newspaper Haluan Padang edition of February 2018th issue will be explained as follows.

\section{Objectivation-Abstraction}

Objectivation is the number of student demonstrations can be said to point to clear numbers, whereas abstraction is the number of student demonstrations can be said to point to unclear figures or by making an abstraction like hundreds, thousands, or lots (Leeuwen, in Eriyanto, 2009, p. 181). The use of Leeuwen's objectivity-type inclusion strategy found on five crime news with narcotics theme on daily online newspaper Haluan Padang edition of February 2018th amounted to 12 data, which is 10 objectivation and 2 abstractions. This can be proved in the example below.

1. "Saat dihitung ganja yang disimpan dalam tiga karung beratnya 73 kilogram (judul berita Bakal diedarkan di Sumbar, 73 Kg Ganja Gagal Diselundupkan)”. 
"When counting marijuana stored in three sacks weighing 73 kilograms (news headlines will be distributed in West Sumatra, $73 \mathrm{~kg}$ of marijuana failed to be smuggled)".

Examples 1 are an inclusion strategy used by news writers with the type of objectivation. It is said to be included in the type of objectivation that the phrase states a clear form of the word clue. For example, in a data quote 1 "Saat dihitung ganja yang disimpan dalam tiga karung beratnya 73 kilogram" can lead the reader by displaying a definite proof of information by pinpointing the amount correctly. In addition, journalists also show that there is no alignment between actors or actors in the news.

News that includes the strategy of inclusion of abstraction types is not caused by journalists' ignorance of certain information, but as a form of news discourse strategy by journalists to show something (Eriyanto, 2009: 181). Based on examples 1 and 2, it indicates that the journalist has displayed clear information and is no longer an abstraction.

\section{Nominated-Categorization}

Nominations are not showing clearly about the actor (someone/group) or about a problem in the news, while the category is clearly showing the actor (someone/group) or about a problem in a news (Leeuwen in Eriyanto, 2009, p. 182). The use of Leeuwen's nomination-type inclusion strategy which was found in five crime news with narcotics theme in daily online newspaper Haluan Padang edition of February 2018th amounted to 11 data, ie 8 data of the nomination type and 3 data of the type of categorization. This can be proved in the following example.

2. "Di jalan Nurul Falah, Simpang Linggarjati, Kelurahan Parupuk Tabing. Kecamatan Koto Tangah, Kota Padang, seorang nelayan ditangkap (Judul berita Bakal Diedarkan di Sumbar, $73 \mathrm{Kg}$ Ganja Gagal Diselundupkan)”.

"On Nurul Falah Street, Simpang Linggarjati, Parupuk Tabing Village. Koto Tangah Subdistrict, Padang City, a fisherman was arrested (Title news Will be circulated in West Sumatra, $73 \mathrm{Kg}$ of Marijuana failed to be smuggled)".

3. "Pelaku yang sehari-hari bekerja sebagai montir di sebuah bengkel motor ini langsung digelandang petugas ke Mapolres Arosuka untuk mempetanggungjawabkan perbuatannya (Judul berita Bawa Ganja, Montir Bengkel di Solok Diciduk Polisi)”.

"The perpetrator who works as a mechanic every day at a motorbike repair shop was immediately accompanied by officers to the Arosuka Police Station to account for his actions (The title of the news Bringing Marijuana, Workshop Mechanic in Solok Arrested by Police)".

In example 2 is an inclusion strategy used by news writers by showing the type of nomination. It is said to be included in the type of nomination that the phrase states the form of an actor that is not displayed clearly. For example on data 2 "Di jalan Nurul Falah, Simpang Linggarjati, Kelurahan Parupuk Tabing. Kecamatan Koto Tangah, Kota Padang, seorang nelayan ditangkap”. Actors or actors are only called nelayan. Nelayan are numerous, so it is not clear who nelayan is pointing to whom. So in this case, it can cause certain prejudices by the public with the uncertainty of the mention of actors or actors clearly against news writing.

In contrast to an example, 3 is an inclusion strategy with a type of categorization that is on the above quotation of the actor is displayed by mentioning the social category, namely, the perpetrator is a day-to-day as a montir. It is in accordance with Leeuwen's perspective that the types of categories that want to be highlighted in the news, and often become valuable information to find out more in the ideology of the media concerned. So in writing the news reporter mentions social categorization and adds understanding of information to the audience.

\section{Assimilation-Individualization}

Individualization is the social actors who are reportedly shown clearly the category, while the assimilation is the social actors who are reported with the unclear category, (Leeuwen in Eriyanto, 2009, p. 187). The use of inclusive assimilation-Individualization Leeuwen strategies found in five criminal news in the narcotics theme in daily online newspaper Haluan Padang edition of February 2018th of 7 data, ie 2 data of assimilation type and 5 data of the type of individualization. This can be proved in the example below.

4. "Seperti yang terjadi Sabtu (3/2) kemarin, seorang pemuda tanggung Reza Januarsal (26) tak berkutik. Saat tim satres Narkoba Polres Solok menciduknya lantaran kedapatan menyimpan Narkotika jenis ganja kering (Judul berita Bawa Ganja, Montir Bengkel di Solok Diciduk Polisi)".

"As happened yesterday (3/2) yesterday, a young man, Reza Januarsal (26), did not move. When the Satres Narcotics team of Solok Police took him because he was found to be 
storing Narcotics from dried marijuana (The title of the news Bringing Marijuana, Workshop Mechanic in Solok Arrested by Police)".

5. "Warga Jorong Dusun Tuo Negari Muaro Bodi Kabupaten Sijunjung itu, diciduk di Jalan lintas Sumatera Jorong Simancung Kanagarian Padang Sibusuk, Kecamatan Kupitan sekitar Pukul 17.30 WIB. Selasa (27/2) (Judul Operasi Antik Singgalang, Polres Sinjunjung Ciduk Pengedar Narkoba). “

"The people of Jorong, Tuo Negari Hamlet, Muaro Bodi, Sijunjung District, were taken away at the Sumatra Cross Road, Jorong Simancung, Kanagarian, Padang Sibusuk, Kupitan District at around 5:30 p.m. Tuesday (27/2) (Title of Antique Singgalang Operation, Sinjunjung District Police Calls for Drug Dealers)".

In example 4 is an inclusion type individualization strategy because the above actor's quotation is clearly displayed. The actor is shown by saying his name so that people can find out who the actor or the culprit is. In the text, the news has confirmed that what was taken in the drug case was a young man named Reza was 24 years old. The affirmation is shown in the news category. This is in contrast to Example 5 in the assimilation inclusion strategy. In the excerpt, the news was not mentioned who the suspect was taken but was referring to warga jorong dusun. It appears that the actor is not displayed clearly. Explanation in the sentence only by mentioning warga jorong dusun. The use of wrong community is still common. So, it is not clear who warga jorong dusun who became suspects.

In this strategy of discourse can cause different meaning. One of them is on the assimilation effect that can create a general opinion. This means that assimilation is often related to identification, how one identifies itself with the group being preached (Eriyanto, 2009, p. 188).

\section{Association-disassociation}

The association is an actor or a party not shown on its own but is associated with another larger group, whereas dissociation is an actor or a party displayed on its own, (Leeuwen in Eriyanto, 2009, p. 189). The use of Leeuwen's association-type disagreement-inclusive strategy found on five crime stories with narcotics theme in daily online newspaper Haluan Padang edition of February 2018th amounted to 6 data, ie 5 data of the association type and 1 data from dissociation theory. This is evidenced in the example below.

6. "Ada sejumlah lokasi penangkapan yang jadi target operasional petugas. Di jalan Nurul Falah, Simpang Linggarjati, Kelurahan Parupuk Tabing. Kecamatan Koto Tangah, Kota Padang, seorang nelayan ditangkap, selanjutnya pada jumat (19/1) diamankan 3 tersangka dengan inisial IA (42) warga Berok, Kelurahan Gunung Pangilun, Padang. YN (47) warga Pamulang Permai, Provinsi Banten dan IK (55) warga Kelurahan Purus (Judul berita Bakal Diedarkan di Sumbar, 73 Kg Ganja Gagal Diselundupkan)".

"There are a number of fishing locations that are operational targets for officers. On Nurul Falah Street, Simpang Linggarjati, Parupuk Tabing Village. Koto Tangah Subdistrict, Padang City, a fisherman was arrested, then on Friday (1/19), 3 suspects were secured with the initials IA (42) Berok residents, Gunung Pangilun Village, Padang. YN (47) a resident of Pamulang Permai, Banten Province and IK (55) a resident of Purus Village (Title news Will be Circulated in West Sumatra, $73 \mathrm{Kg}$ of Marijuana Failed to be Smuggled)”.

Examples 6 is an inclusion type strategy of association. In Example 6 the actor is associated with another larger group and where the social actors are located. The so-called nelayan were arrested on jalan Nurul Falah, linked to the arrest of other actors "IA" "YN" and "IK" who was arrested the next day. This type of inclusion strategy of this type of association in this news discourse is seen as a wider case and has great significance (glorification), and is depicted in its entirety. This type of association makes the audience able to imagine and connect imaginary with the wider community (Eriyanto, 2009, p. 191).

The use of disassociation type inclusion strategies found can be demonstrated in the following examples.

7. "Ia mengatakan, sebelumnya pelaku berjumlah dua orang. Namun, rekannya tersebut berhasil melarikan diri disaat petugas melakukan pengejaran salah seorang tersangka. (Bawa 19 Paket Ganja, Seorang Pria Diciduk Polres Pasaman)".

"He said, previously there were two perpetrators. However, his colleague managed to escape when officers chased one of the suspects. (Bring 19 Marijuana Packages, A Man Taken by Pasaman District Police)".

In contrast to Examples 6, in Example 7 is the use of disassociation type inclusion strategies because in the above sentence the actor is not associated with other actors. Actors are only mentioned alone without being linked with others. In this case, it is seen as a specific case, local, and not depicted in its entirety. 
From the results of these findings can authors conclude in writing criminal news with the narcotics of journalists does not marginalize the victim. This is evident from reporters writing down the name of the perpetrator and explaining what mistakes committed by the perpetrator, as well as reporters also explain the punishment of the perpetrator. This can be proven from the following example.

8. "Pengguna narkoba jenis sabu itu bernama Frengki Malaye Raksa (37) warga Jalan Merpati II RT 04, RW 05, Komplek Pondok Permai Garut, Kecamatan Pauh. Frengky ditangkap oleh tim unit Reskrim Polsek Lubuk Begalung di Jalan Lingkar Ulu Gadut, Kelurahan Limau Manis Selatan, Kecamatan Pauh tanpa perlawanan saat personel membekuknya (Judul berita Simpan Sabu dalam Helm, Frengki Diciduk Polisi)".

"The methamphetamine drug user was named Frengki Malaye Raksa (37) a resident of Jalan Merpati II RT 04, RW 05, Pondok Permai Garut Complex, Pauh District. Frengky was arrested by a team of the Lubuk Begalung District Police Criminal Investigation Unit at Jalan Lingkar Ulu Gadut, South Limau Manis Village, Pauh District without resistance when personnel arrested him (Title of Save Sabu in Helm, Frengki Arrested by Police)".

Based on examples 8 it can be proven that journalists do not marginalize the victim. The alignment of journalists can be seen from the way journalists mention the names of the perpetrators, the crimes committed perpetrators, and sanctions to be given to the perpetrators. However, of the five news headings analyzed, the author found a news headline found not mentioned by the journalist, namely the title of the news Bakal Diedarkan di Sumbar, $73 \mathrm{Kg}$ Ganja Gagal Diselundupkan. In the headline despite the name of the perpetrator mentioned, there are other actors who report the name of the perpetrator by using the initials or suspects only. By not mentioning the name of the actor means the writer has been slightly aligned to the actor, as the author tries to hide the identity of the actual actor or actor. This can be proved in the example below.

9. “Ada sejumlah lokasi penangkapan yang jadi target operasional petugas. Di jalan Nurul Falah, Simpang Linggarjati, Kelurahan Parupuk Tabing. Kecamatan Koto Tangah, Kota Padang, seorang nelayan ditangkap, selanjutnya pada jumat (19/1) diamankan 3 tersangka dengan inisial IA (42) warga Berok, Kelurahan Gunung Pangilun, Padang. YN (47) warga Pamulang Permai, Provinsi Banten dan IK (55) warga Kelurahan Purus (Judul berita Bakal Diedarkan di Sumbar, 73 Kg Ganja Gagal Diselundupkan)”.

"There are a number of fishing locations that become operational targets for officers. On Nurul Falah Street, Simpang Linggarjati, Parupuk Tabing Village. Koto Tangah Subdistrict, Padang City, a fisherman was arrested, then on Friday (1/19), 3 suspects were secured with the initials IA (42) Berok residents, Gunung Pangilun Village, Padang. YN (47) a resident of Pamulang Permai, Banten Province and IK (55) a resident of Purus Village (Title news Will be Circulated in West Sumatra, $73 \mathrm{Kg}$ of Marijuana Failed to be Smuggled)".

Based on examples 9 it is seen that journalists side with the perpetrator by not mentioning the perpetrator's name completely. Though journalists already know the name of the perpetrator because the perpetrator has been caught.

\section{CONCLUSION}

Based on the discussion it can be concluded that in writing criminal news with the theme of narcotics as whole journalists do not side with the perpetrators or actors. The form of impartiality of journalists to perpetrators is to mention the names and crimes of perpetrators and sanctions that will be given to the perpetrators for the deeds that have been done. The descriptions of these findings are tailored to Theo Van Leeuwen's perspective based on inclusion strategies (how the characters or actors are depicted in the news text).

The type of inclusion strategy Theo Van Leeuwen found in five crime news with narcotics theme in daily online newspaper Haluan Padang edition of February 2018th as follows: (1) the use of Leeuwen's ObjectivationAbstraction found in daily online newspaper Haluan Padang edition of February 2018th amounted to 12 data, (2) the usage of Leeuwen nominated-category found in daily online newspaper Haluan Padang edition of February 2018th to 11 data, (3) the use of Leeuwen Self-assimilation found in daily online newspaper Haluan Padang edition of February 2018th amounted to 7 data, (4) the use of the Leeuwen Association-disassociation found in daily online newspaper Haluan Padang edition of February 2018th amounted to 6 data.

This finding is expected to provide references in knowledge, especially critical discourse analysis. The author's suggestion can be given to some parties especially to (1) the reader, that if reading the information in the newspaper do not easy to believe the writing, it is expected that the reader first find out the truth by analyzing by using critical discourse analysis and (2) interested in research by using critical discourse analysis is expected to develop the use of Van Leeuwen's perspective with different aspects or objects in a study as an addition to the knowledge of the author and the reader. 


\section{References}

Alfianika, N. (2016). “Analisis Wacana Kritis Teori Inclusion Theo Van Leeuwen Dalam Berita Kriminal Tema Pencurian Koran Posmetro Padang Edisi Mei 2013”. Jurnal Penelitian Bahasa dan Sastra Indonesia 2 (1). https://media.neliti.com/media/publications/80120-ID-analisis-wacana-kritis-teori-inclusion-t.pdf .Diunduh pada tanggal 20 Februari 2018.

Eriyanto. (2001). Analisis Wacana: Pengantar Teks Media. Yogyakarta: LKiS.

Harling., M. (2013) “Examining”The Police”: On Inclusion and "Investmentality" in Swedish Schooling”. (Jurnal European Education Vol. 45 No. 3). https://eric.ed.gov/?q=Discourses+of+inclusion\&id=EJ1033618 . Diunduh pada tanggal 08 Juni 2018.

Harian Haluan, Padang. (2018). Bakal Diedarkan di Sumbar, 73 Kg Ganja Gagal Diselundupkan. Dalam Berita Kriminal 01 Februari 2018.

Harian Haluan, Padang. (2018). Bawa Ganja, Montir Bengkel di Solok Diciduk Polisi. Dalam Berita Kriminal 05 Februari 2018.

Harian Haluan, Padang. (2018). Pengedar Sabu Jalani Sidang Perdana di Padang. Dalam Berita Kriminal 06 Februari 2018.

Harian Haluan, Padang. (2018). Simpan Sabu dalam Helm, Frengki Diciduk Polisi. Dalam Berita Kriminal 27 Februari 2018.

Harian Haluan, Padang. (2018). Bawa 19 Paket Ganja, Seorang Pria Diciduk Polres Pasaman. Dalam Berita Kriminal 27 Februari 2018.

Harian Haluan, Padang. (2018). Bawa Sabu, Atlet Judo di Padang Diciduk Polisi. Dalam Berita Kriminal 13 Februari 2018.

Harian Haluan, Padang. (2018). 2017, 5 Kasus HIV di Payakumbuh Berasal Dari LSL. Dalam Berita Kriminal 08 Februari 2018.

Harian Haluan, Padang. (2018). Miliki Sabu, IRT di Padang Divonis 4 Tahun. Dalam Berita Kriminal 15 Februari 2018.

Harian Haluan, Padang. (2018). Musnahkan Barang Bukti, 6 Kg Ganja dibakar di depan Pejabat Payakumbuh dan Lima Puluh Kota . Dalam Berita Kriminal 14 Februari 2018.

Harian Haluan, Padang. (2018). Pesta Ganja di Kuburan, Tiga Pelajar di Agam Diciduk . Dalam Berita Kriminal 14 Februari 2018.

Harian Haluan, Padang. (2018). Dua Siswa di Limapuluh Kota Terlibat Narkoba, Guru: Ia Butuh Uang, Orangtuanya di Penjara. Dalam Berita Kriminal 19 Februari 2018.

Harian Haluan, Padang. (2018). Rutan Sasaran Peredaran Narkoba. Dalam Berita Kriminal 19 Februari 2018.

Harian Haluan, Padang. (2018). Sempat Kejar-kejaran, Tersangka Penyelundupan 47 Kilogram Ganja di Pasaman Diciduk. Dalam Berita Kriminal 19 Februari 2018.

Harian Haluan, Padang. (2018). Bawa Ganja, Siswa SMA di Solok Ini Diciduk Polisi. Dalam Berita Kriminal 19 Februari 2018.

Hodkinson., A. (2013) "All Present and Correct?" Exclusionary Inclusion within the English Educational System". (Jurnal Critical Education Policy $\quad$ Studies https://eric.ed.gov/?q=Discourses+of+inclusion\&id=EJ973669 .Diunduh pada tanggal 08 Juni 2018.

Moleong, L. J. (2007). Metodologi Penelitian Kualitatif. Bandung: Rosdakarya.

Nazir, M. (1988). Metode Penelitian. Jakarta: Ghalia Indonesia.

(2008). "Ketidakadilan (Wacana Pembandingan Aktor Berita Kriminal di Headline Surat Merapi)". Jurnal Ilmu Komunikasi, 5 (1). https://ojs.uajy.ac.id/index.php/jik/article/view/220/309 Diunduh pada tanggal 08 Juni 2018.

Remley, D. (2009) “Training within Industry as Short-Sighted Community Literacy-Appropriate Training Program: A Case Study of Worker-Centered Training and Its Implications". (Jurnal Community Literacy Vol. 3 No. 2). https://eric.ed.gov/?q=Discourses+of+inclusion+theo+van+leeuwen\&id=EJ872402. Diunduh pada tanggal 08 Juni 2018.

Silitonga., O. (2016). “Implementasi Analisis Wacana Kritis Perspektif Leeuwen Dalam Berita Politik Surat Kabar Padang Ekspres Terhadap Pembelajaran Bahasa Berbasis Teks". (Jurnal Fakultas Bahasa dan Sastra Universitas Putera Batam Vol. 1 No. 2). http://jurnal.unmuhjember.ac.id/index.php/BB/article/view/397 . Diunduh pada tanggal 09 Februari 2018. 
Tange., H. (2016) “Inclusive and Exclusive Knowledge Practices in Interdisciplinary, International Education”. Journal Internasional Inclusive Education, 20 (10). https://eric.ed.gov/?q=Discourses + of + inclusion\&id=EJ1105935 . Diunduh pada tanggal 08 Juni 2018.

Trilokekar, Desai, El Masri, Amira (2017) "The "'[H]unt for New Canadians Begins in the Classroom": The Construction and Contradictions of Canadian Policy Discourse on International Education". Jurnal Globalisation, Societies

and

Education

15

(5). https://eric.ed.gov/?q=Discourses + of + inclusion+theo+van+leeuwen\&id=EJ1154252. Diunduh pada tanggal 08 Juni 2018. 